\title{
Zika virus infection in the Brazilian Amazon: A case report
}

\author{
Cheila Maria Lins Bentes ${ }^{1}$, Marcos do Nascimento Bentes ${ }^{2}$, Kátia Cilene Godinho Bertoncello ${ }^{3}$,Jussara Gue Martini ${ }^{3}$, Fernanda Beduschi \\ Antoniolli Neves ${ }^{4}$ and Maria de Lourdes de Souza ${ }^{3 *}$ \\ ${ }^{1}$ University of State of Amazonas (DINTER UFSC/UEA), Brazil \\ ${ }^{2}$ HEMOAM Foundation, Manaus, Amazonas, Brazil \\ ${ }^{3}$ Graduate Nursing Program at UFSC (PPGEn/UFSC), Federal University of Santa Catarina, Florianópolis, Santa Catarina, Brazil \\ ${ }^{4}$ FAPESC Foundation, Florianópolis, Santa Catarina, Brazil
}

\begin{abstract}
This study aims to report a case of Zika virus infection in a pregnant woman living in the city of Manaus, Amazonas, Brazil, describing the epidemiological characteristics related to the person, the time, and the clinical aspects of the pregnancy. The case of a 23-year-old pregnant woman living in the eastern part of the city. In the eighth gestational week, she sought care at the Emergency Care Service because she had fever, itchy rash, diarrhea, vomiting, nausea, headache, retro orbital pain, and myalgia. The urine and serology were collected for laboratory examination at the Tropical Medicine Foundation, so that Zika virus infection was confirmed. The neonate was born at 37 weeks with a head circumference of $29 \mathrm{~cm}$ and underwent transfontanellar ultrasound, presenting ultrasound signs suggestive of microcephaly and presence of hydrocephalus. The succession of severe congenital anomalies related to Zika infection in pregnancy has a significant impact on families, especially those already facing economic difficulties, thus justifying this case report.
\end{abstract}

\section{Introduction}

During pregnancy, women go through physiological and psychosocial changes considered normal at this phase; on average one in five women have symptoms of distress. Having to face a disease prone to cause congenital abnormalities in the fetus or newborn further increases the psychological stress of pregnant women. The multidisciplinary team must ensure the physical and psychological well-being of these pregnant women throughout pregnancy [1].

News disseminated in national and international media in 2015 generated social unrest, mobilization of the scientific community, declaration of a national public health emergency by the Ministry of Health, and public health emergency of international concern by the World Health Organization [2].

This was the hypothesis formulated by neuropediatrician of public hospitals in the city of Recife. They reported a 20 -fold increase in cases of congenital microcephaly associated with brain abnormalities related to Zika virus (ZIKV) infection during pregnancy, considering the spatiotemporal correlation and clinical-epidemiological characteristics of the two pathologies [3].

As part of the research in Brazil, reported findings in two pregnant women from Paraíba, a state affected by the ZIKV epidemic, representing the first evidence consistent with intrauterine transmission [4].

The clinical manifestations of the disease in pregnant women are similar to those in adult individuals. One study reports low fever, maculopapular rash with or without pruritus as the most frequent symptom followed by conjunctivitis, myalgia/arthralgia, lymphadenopathy, headache, others [5]. The symptoms regress after three to seven days. In $80 \%$ of cases, ZIKV infection can be asymptomatic $[2,6,7]$.

During an outbreak beginning in October 2013 in French Polynesia, South Pacific, was described in their clinical and laboratory studies evidence of the virus in the serum of two newborns of two mothers with confirmed diagnosis of Zika virus using the reverse transcriptase polymerase chain reaction technique (RT-PCR) [8].

The virus crosses the placental barrier during the period of pregnancy or at birth, causing congenital infection. The virus was detected in the amniotic fluid, placenta and fetal tissues [7,9]. Regarding the importance of the risk of vertical transmission, the author recommended the separate analysis after maternal Zika infection; the infection rate of the fetoplacental unit; and if infection occurs, the rate of fetal sequelae [5].

Neurotropism of ZIKV is supported by research on fetal necropsy with viral isolation by RT-PCR in brain tissues, suggesting that the insult occurred in the early stage of embryogenesis $[6,10]$.

Inadequate brain development leads to congenital malformations triggered by a number of factors of different causes such as exposure to chemicals, pathogens and radiation. One of these conditions is microcephaly, defined as head circumference (HC) values below the pattern of growth curves at birth, which may or may not be associated with central nervous system (CNS) impairment and cognitive impairment. Neuroimaging and laboratory tests facilitate the investigation of congenital anomalies [3].

The Ministry of Health is in accordance with the World Health Organization on recommendations for parameters for determining microcephaly levels [11], namely:

${ }^{\star}$ Correspondence to: Maria de Lourdes de Souza, Instituto Repensul, Centro de Ciências da Saúde, Universidade Federal de Santa Catarina, Rua Delfino Conti, s/n-Trindade, CEP 88040-370, Florianópolis/SC - Brazil, Tel: +55 (48) 991618333; E-mail: repensul@uol.com.br

Key words: microcephaly, zika virus, pregnancy, newborn

Received: March 27, 2020; Accepted: April 09, 2020; Published: April 13, 2020 
- Microcephaly: Newborns with head circumference less than 2 standard deviations (SD) below the mean for gestational age and sex.

- Severe microcephaly: Newborns with head circumference of less than 3 standard deviations for gestational age and sex.

The April 2017 Epidemiological Bulletin of the Ministry of Health showed data on daily reported cases of microcephaly related to Zika virus infection during pregnancy in the country, making a total of 2,653 confirmed cases in the period 2015-2017, with effects on child growth and development [11]. According the other study of the 3,374 confirmed cases of congenital Zika syndrome in American countries, $82 \%$ occurred in Brazil [3].

Early identification of congenital Zika syndrome during prenatal care may favor successful care actions by health professionals, as well as collaborate with individual and collective measures aimed at appropriate preparation and guidance of pregnant women and their families for the birth of a syndromic newborn[1,7].

Zika virus infection is declining in some countries, but continues to advance geographically in regions with competent vectors, so that recommendations on strict surveillance are still valid [12]. Since 2013, more than 30 countries have reported cases of congenital malformations of the central nervous system associated with ZIKV infection [13]. The present case report is justified by the impact of the epidemic on the population whose extent involves the death of the affected people, especially those with associated neurological diseases.

The succession of severe congenital anomalies related to ZIKV infection in pregnancy, especially when contracted in the first trimester of pregnancy, has a significant impact on families, especially those already facing economic hardship [14].

The following scenario was defined as the objective of this study: To report the case of ZIKV infection in a pregnant woman who lives in the city of Manaus, Amazonas, Brazil (Brazilian Amazon), describing the epidemiological characteristics related to the person, time and clinical aspects of the pregnancy.

\section{Result}

The largest rainforest in the world is found in the state of Amazonas. Its biodiversity is high and derived from geological and climatic transformations, presenting about $90 \%$ of its area preserved. Combining its ecological potential with a business policy based on sustainability, Manaus became the $6^{\text {th }}$ richest city in the country when evaluated according to the municipal Gross Domestic Product (GDP) [15].

The data of this case report were collected from the Department of Environmental and Epidemiological Surveillance of the Strategic Health Surveillance Information Center (CIEVS) of the Municipal Health Secretariat (SEMSA), Manaus city/Amazonas, Brazil. The case of one pregnant woman with ZIKV infection notified and whose diagnosis was confirmed by clinical and laboratory examination in 2016 was selected for the study.

Data were collected after obtaining a favorable opinion from the Research Ethics Committee of the Amazonas State University (CEPUEA) and letters of authorization from SEMSA and CIEVC. The data collected were systematized in an electronic folder in Google Drive.

23-year-old pregnant woman, brown skinned, in stable union, housewife, incomplete elementary school, family income less than 1 minimum wage, resident in the eastern part of the city, did not travel during the gestational period.
Regarding obstetric history, the following information was registered in the medical record: Gestations 05, cesarean sections 02, abortions 02; no kinship with the mate; absence of congenital malformation; she is not aware of cases of microcephaly in the family; denies continuous drug use; did not undergo any treatment for sexually transmitted infections; she was treated during pregnancy for anemia, from May 19 on started the use of iron and folic acid.

During pregnancy, she had no contact with pesticides, agro-toxins, chemicals and X-rays. Date of last menstruation 10/02/2016, with probable date of birth 17/11/2016. Her first and only consultation at the Basic Health Unit (BHU) was on 19/05/2016, the next day she went to the BHU to be vaccinated, receive the DT vaccine, did not attend the other consultations, SIC, "there was never vacancy". She denies the use of illicit drugs, smoking and alcohol.

On the eighth week, the first trimester of pregnancy, she was admitted to a SPA, diagnosed with dehydration. She presented the following signs and symptoms: fever, itchy rash, diarrhea, vomiting, nausea, headache, retro-orbital pain, and myalgia, and used painkillers for five days under medical advice.

She was referred to Tropical Medicine Foundation of Manaus/ Amazonas, Brazil (FMTM) which screens suspected cases of ZIKV infection. Notification on 13/04/2016 and collection of material for examination of serology and urine. The examination was made by real time RT-PCR. Symptom onset on April 8, collection of material after 5 of symptom onset. Results of the examination 42 days after collection, and thus 47 days passed between symptom onset and the release of the results of the serology and urine examination: both detectable (positive).

She was assisted during delivery by the multi professional team at the public maternity hospital in the east of the city. The newborn was born on 12/10/2016, through cesarean section, it was female, 37 weeks, with the following measurements recorded in the child's book: Weight: $2240 \mathrm{~kg}$, height: $45 \mathrm{~cm}, \mathrm{HC}: 29 \mathrm{~cm}$ (severe microcephaly), APGAR $07 / 08$.

During pregnancy, she underwent 4 ultrasounds (US) (three obstetric and one morphological), Table 1, all without medical request, with the results (Table 1).

At the maternity ward, the following examinations, procedures and referrals were performed:

Tests: neonatal response to heel prick; eye test - retinopathy test, results show no alterations; hearing screening, results show alterations and suggestion to review after 15 days; heart test, results show no

Table 1. Imaging exams performed during pregnancy

\begin{tabular}{|l|l|}
\hline Imaging Tests & Obstetric ultrasound \\
\hline Request & Diagnostic Hypothesis \\
\hline Date & $\begin{array}{l}\text { Closed endocervical canal. } \\
\text { Free bottom Douglas bag. } \\
\text { Single 10-week (+/ - 3 days) topical pregnancy }\end{array}$ \\
\hline $\begin{array}{l}\text { 4/04/2016 } \\
\text { US 6-12 weeks }\end{array}$ & $\begin{array}{l}\text { Single 15.5-week (+/- 1.0 week) topical pregnancy } \\
\text { 13/05/2016 } \\
\text { US over 12 weeks }\end{array}$ \\
\hline $\begin{array}{l}\text { 12/10/2016 } \\
\text { US over 12 weeks }\end{array}$ & $\begin{array}{l}\text { Biometrics compatible with topical gestation of 30 weeks. } \\
\text { Manual biometrics matches the previous exams. }\end{array}$ \\
\hline Request & Fetal morpholing with asymmetrical growth restriction of the fetus. \\
\hline $\begin{array}{l}12 / 10 / 2016 \\
\text { Private clinic }\end{array}$ & $\begin{array}{l}\text { Morphological examination without echographic alterations. } \\
\text { NOTE: Trivascular umbilical cord. }\end{array}$ \\
\hline
\end{tabular}


alterations; tongue test shows no alterations; trans fontanelle USG on the fourth day of life (Figure 1).

Procedures: Notification; vaccination - BCG and Hepatitis B; guidance and stimulation of breastfeeding.

\section{Discussion}

Similar sociodemographic characteristics were observed in the US Virgin Islands [16] and in the state of Mato Grosso, Midwest Brazil [17], with pregnant women infected with Zika virus. The pregnant women most affected by the disease are poor, with low schooling, living in areas of the city with inadequate environmental management, and often lack of health facilities. Their homes become suitable places for breeding disease-carrying insects such as Aedes aegypti.

The city of Manaus, Amazonas, Brazil, has $26.3 \%$ of the urban households of its territory on public roads with adequate urbanization (presence of manholes, sidewalks, paved streets and curbs), and over $70 \%$ of the population lives in neighborhoods without proper environmental management [18].

The pregnant woman did not attend prenatal care consultations. The assistance of the multiprofessional team during prenatal care aims to identify early health problems of the mother and child. Professionals should act to prevent or minimize the probable risk factors that may determine an unfavorable outcome to the pregnancy cycle and contribute to the physical and mental well-being of the mother/child binomial [19].

The most frequently reported signs and symptoms are mild fever, rash, pruritus, headache, arthralgia, myalgia, non-purulent conjunctivitis, and vomiting. A comparison with our research showed similarity in relation to the reported signs and symptoms. There is no treatment and vaccine for Zika; symptomatic relief is the only recommendation of the Ministry of Health. The patient used painkillers under medical guidance [20].

Zika virus infection is a disease of compulsory notification and is on the National List of Diseases, Health Problems and Public Health Events of Compulsory Notification. Zika virus infection was included in this list by the Ordinance $n^{\circ} 204$ of February 17, 2016, of the Ministry of Health, because of the impact that it can have on the health of women, the fetus and the family [2].

Vector transmission is the main means of dissemination, but the disease can be transmitted through condomless sex, blood transfusion, and from mother to fetus. Pregnant women can be exposed and infected with the virus at any trimester of pregnancy, transmitting it to the fetus [21].

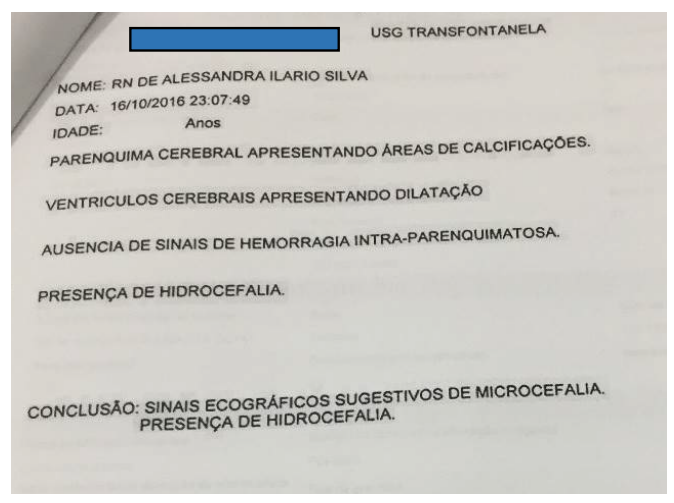

(a)

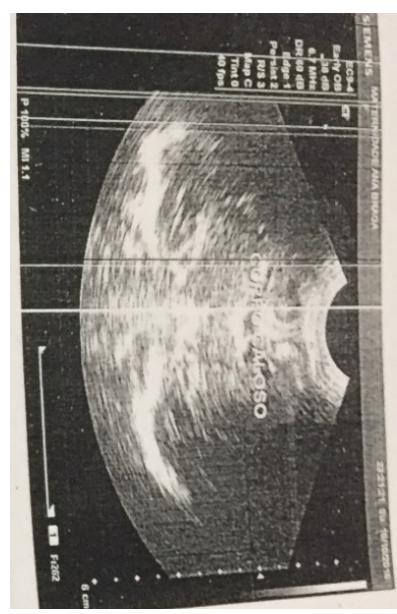

(b)

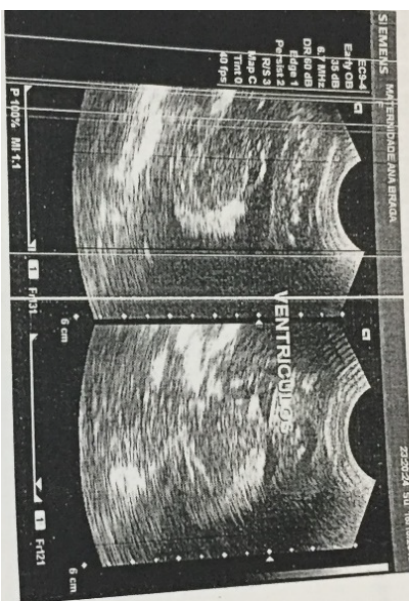

(c)

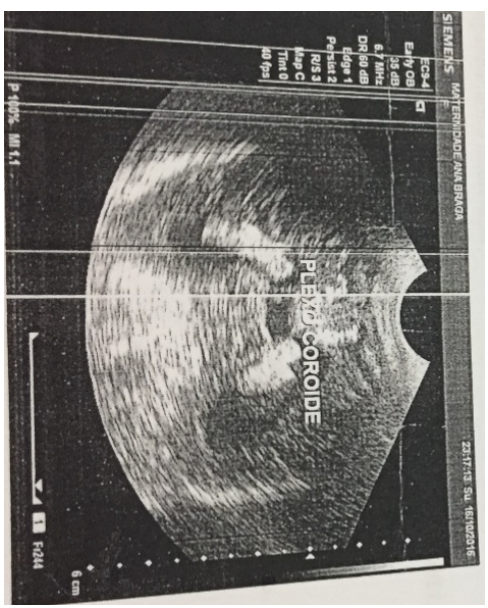

(d)

Figure 1. Trans fontanelle USG image and report. (a) Clinical report: brain parenchyma showing areas of calcification. Brain ventricles showing dilation. No signs of intra parenchymal hemorrhage. Presence of hydrocephalus. Conclusion: Ultrasound signs suggestive of microcephaly and presence of hydrocephalus; (b) Trans fontanelle USG image; (c) Trans fontanelle USG image; (d) Trans fontanelle USG image 
Examination using serum is recommended within 5 days after the onset of symptoms because viremia is limited and the decrease in viral load in the maternal blood is rapid after the onset of rash. Zika virus RNA can be screened and detected in the urine within a longer period, 20 days from the onset of symptoms. Virus detected in saliva, breast milk, semen and cervical and uterine secretions, and amniotic and cerebrospinal fluids [22].

The results of the real-time reverse transcription polymerase chain reaction (RT-PCR) in serum and urine material collected on the fifth day after the onset of signs and symptoms were noted in the patient's medical record, staying within the time recommended in the literature, with positive result: detectable.

Diagnostic-specific laboratory tests such as RT-PCR detect viral particles and suggest that the pregnant woman had contact with the virus, but it does not unequivocally indicate that the fetus was infected or will present congenital abnormalities associated with the disease [23]. Ultrasound evidence of birth defects associated with ZIKV infection is a way to try to prevent probable complications to the fetus [24].

To provide results of laboratory examination to detect Zika virus infection, was recommended basal fetal ultrasound [25]. If there is ultrasound evidence of fetus with congenital Zika syndrome, the case must be referred to a fetal medicine service and/or to High Risk Prenatal Care (HRPC). If ultrasound results do not show any abnormality, the pregnant woman should be followed in HRPC, following the guidelines of the Ministry of Health [19]. This follow-up did not occur in the case analyzed, because the patient did not attend prenatal care consultations.

Microcephaly may point to the tip of an iceberg of consequences related to ZIKV infection in pregnancy. Congenital malformations are now called congenital Zika syndrome (CZS) and encompass a number of neurological, eye, skeletal, genitourinary changes among others [26].

The risk of fetal congenital abnormalities exists, since the pregnant woman may be infected with Zika virus at any gestational age; however, when infection occurs during the first trimester of pregnancy, a highest incidence of congenital malformations is caused by the virus. The patient was infected with the virus in the first trimester of pregnancy (eighth week), and the infection was confirmed by urine and serology tests.

The termination of gestation culminated in the birth of a child with microcephaly and central nervous system disorders. The embracement by health professionals of families who have with children with chronic diseases that require specific care, who will be always dependent on others for their basic human needs, help relieve the burden and family suffering [27].

\section{Conclusion}

The main limitation of this study is the data collection performed in medical records, with data already recorded by others and, therefore, researchers have no control over their quality.

Health professionals face a new teratogen factor caused by Zika. Unraveling the pathogenic mechanisms for preventive coping and early recognition of clinical manifestations, especially those related to the growth and development of children is essential for the development of intervention and care programs for the children and families involved.

Associated with the severe neurological impact in the children the infection by the Zika virus has clearly emerged as a public health problem and which requires much scientific study. Nonetheless, the social impact remains associated with Zika virus infection and require continued research efforts to evaluate the reproduction and dissemination the virus and the preventive and clinic actions in the world.

\section{References}

1. Lima KMSG, Santos JS, Pereira J, Barbosa LP, Cabral MCAM, et al. (2019) Nursing care at high-risk prenatal care. Braz J Hea Rev 2: 3183-3197.

2. BRASIL (2016) Zika abordagem clínica na atenção básica. Brasília: Ministério da Saúde.

3. Albuquerque MFPM, Souza WV, Araújo TVB, Braga MC, Miranda-Filho DB, et al. (2018) Epidemia de microcefalia e vírus Zika: A construção do conhecimento em epidemiologia. Cad Saúde Pública 34: e00069018.

4. Oliveira M, Malinger G, Ximenes R, Szejnfeld PO, Sampaio SA, et al. (2016) Zika virus intrauterine infection causes fetal brainabnormality and microcephaly: Tip of the iceberg? Ultrasound Obstet Gynecol 47: 6-7.

5. Lin HZ, Tambyah PA, Yong EL, Biswas A, Chan SYA (2017) Review of Zika virus infections in pregnancy and implications for antenatal care in Singapore. Singapore Med J 58 : 171-178. [Crossref]

6. Alvino ACMI, Melo LRM, Oliveira JAMM (2016) Association of arthrogryposis in neonates with microcephaly due to Zika virus -a case serie. Rev Bras Saúde Matern Infant. 16: S83-S88.

7. Salge AKM, Castral TC, Souza RRG, Minamisava R, Souza SMB (2016) Infecção pelo vírus Zika na gestação e microcefalia em recém-nascidos: revisão integrativa de literatura. Rev Eletr Enf 18: e1137.

8. Besnard M, Lastere S, Teissier A, Cao-Lormeau V, Musso D (2014) Evidence of perinatal transmission of Zika virus, french polynesia, december 2013 and february 2014. Euro Surveill 19: 1-4.

9. Martínez de Salazar P, Suy A, Sánchez-Montalvá A, Rodó C, Salvador F, et al. (2016) Zika fever. Enferm Infecc Microbiol Clin 34: 247-252.

10. Mlakar J, Korva M, Tul N, Popović M, Poljšak-Prijatelj M, et al. (2016) Zika Virus associated with microcephaly. N Engl J Med 374: 951-958. [Crossref]

11. BRASIL (2017) Monitoramento integrado de alterações no crescimento e desenvolvimento relacionadas à infecção pelo vírus Zika e outras etiologias infecciosas, até a Semana Epidemiológica 14/2017. Boletim Epidemiológico. Brasília 13: 1-9.

12. WHO. Zika virus country classification scheme. Interim guidance. Genebra: World Health Organisation, 2017.

13. WHO. Pregnancy management in the context of Zika virus infection. Geneva: World Health Organization, 2016.

14. Harris LH, Silverman NS, Marshall MF (2016) The paradigm of the paradox: Women, pregnant women, and the unequal burdens of the Zika Virus pandemic. Am J Bioeth 16: 1-4. [Crossref]

15. GEA. Amazonas. Economia. Dados. Governo do Estado do Amazonas, 2015.

16. Prue CE, Roth JN Jr, Garcia-Williams A, Yoos A, Camperlengo L, et al. (2017) Awareness, beliefs, and actions concerning zika virus among pregnant women and community members -- U.S. Virgin Islands, November-December 2016. MMWR Morb Mortal Wkly Rep 66: 909-913. [Crossref]

17. Sousa CA, Mendes DCO, Mufato LF, Queirós OS (2018) Zikavírus: Knowledge, perceptions, and care practices of infected pregnant women. Rev Gaúcha Enferm 39: e20180025.

18. BRASIL. IBGE Cidades 2017 [Internet]. Rio de Janeiro: IBGE, 2017.

19. BRASIL. Ministério da Saúde. Atenção ao pré-natal de baixo risco. Brasília: Ministério da Saúde, 2012.

20. Esposito DA, Moraes JB, Fonseca BAL (2017) Current priorities in the Zika response. Immunology 153: 435-442.

21. Petersen EE, Staples JE, Meaney-Delman D, Fischer M, Ellington SR, et al. (2016) Interim guidelines for pregnant women during a zika virus outbreak - United States, 2016. MMWR Morb Mortal Wkly Rep 65: 30-33. [Crossref]

22. Pereira AM, Monteiro DLM, Werner H, Daltro P, Fazecas T, et al. (2018) Zika virus and pregnancy in Brazil: What happened? J Turk Ger Gynecol Assoc 19: 39-47. [Crossref]

23. Mota VMR, Cavalcanti LPG, Delfino AS, Lopes TECF, Pessoa ALS, et al. (2018) Abortion in cases of zika virus congenital infection. Rev Bras Ginecol Obstet 40: 417 514. [Crossref] 
24. Holtzman M, Golden WC, Sheffield JS (2018) Zika virus infection in the pregnant woman. Clin Obstet Gynecol 61: 177- 185.

25. Affini AMS, Rocha SN, Silva SA, Leite EPRC, Terra FS, et al. (2017) Conduct of nurses about the zika virus in the prenatal consultation. Rev enferm UFPE on line 11: 5231-5244.
26. Alvarado MG, Schwartz DA (2017) Zika virus infection in pregnancy, microcephaly, and maternal and fetal health: What we think, what we know, and what we think we know. Arch Pathol Lab Med 141: 26-32. [Crossref]

27. Sousa EFR, Costa EAO, Dupas G, Wernet M (2013) Continued care for families of children with chronic diseases: perceptions of family health program teams. Rev Esc Enferm USP 47: 1367-1372.

Copyright: (C2020 Bentes CML. This is an open-access article distributed under the terms of the Creative Commons Attribution License, which permits unrestricted use, distribution, and reproduction in any medium, provided the original author and source are credited. 